\title{
Maxillofacial tumors and tumor-like lesions in a Nigerian teaching hospital: an eleven year retrospective analysis
}

\author{
Bassey GO, Osunde OD, Anyanechi CE
}

Department of Dental and Maxillofacial Surgery, University of Calabar Teaching Hospital, Calabar, Nigeria

\begin{abstract}
Background: This paper reviews the types, prevalence and demographic distribution of maxillofacial tumors, cysts and tumor-like lesions in a Nigerian population.

Methods: A retrospective analysis of the medical records and histological reports of patients with oral and maxillofacial tumors and cystic lesions who presented to the Maxillofacial Unit of our institution over an eleven year period was undertaken. Information on demographics, histological diagnosis and clinical presentation were obtained and analyzed. A p value of less than 0.05 was considered significant.

Results: A total o:f 146 patients, aged 5-70 years (mean 30.5 \pm 12.9) were seen over the period of study. There were 96 males $(65.8 \%)$ and 50 females $(34.2 \%)$ giving a male to female ratio of almost 2:1. Benign tumors accounted for 124, $86.3 \%$ and malignant tumors $(22,13.7 \%)$. Ameloblastoma was the most prevalent benign tumor observed $(53,36.3 \%)$ while squamous cell carcinoma was the most common malignant tumor. The peak age of ameloblastoma was the fourth decade and squamous cell carcinomas the sixth and seventh decades of life. Jaw swellings were the most common presentation (98, $67.1 \%)$, followed by pain $(23,15.9)$. The duration of symptoms on presentation ranged from 1 to 96 months (mean 23.32 $\pm 15.72)$ and this was not different for malignant or benign tumors $(\mathrm{P}=0.886)$.

Conclusion:Late presentation still remains the main challenging factor in the early detection and management of maxillofacial tumors in our environment. More awareness campaign is necessary, especially at the primary health care level, to educate the populace on the need for early presentation at treatment centers.
\end{abstract}

Keywords: Tumors, maxillofacial, Nigeria

African Health Sciences 2014;14(1): 56-63 http://dx.doi.org/10.4314/ahs.v14i1.9

\section{Introduction}

The maxilla and the mandible are the sites of many cystic and neoplastic conditions which could be either benign or malignant. ${ }^{1}$ Swellings in the orofacial region are unique due to the obvious cosmetic defect and functional impairment of the anatomically related aerodigestive tract. Orofacial tumors are known to exhibit geographic variations in prevalence and pattern due to cultural, social, occupational or climatic factors as shown by studies from Nigeria ${ }^{2,3}$, other African countries ${ }^{4,5}$, Asia ${ }^{6}$ and Western nations. ${ }^{7,8}$ Wakiaga et al. ${ }^{9}$ in a report from Kenya found ameloblastoma,Burkitt's lymphoma, ossifying fibroma and osteogenic sarcoma as the most common tumors in that order.

\section{Correspondence author:}

O.D.Osunde

Department of Dental and Maxillofacial Surgery

University of Calabar Teaching Hospital

Calabar, Nigeria

Email:otdany@yahoo.co.uk
In Nigeria, there are several reports of oral and maxillofacial odontogenic and non-odontogenic tumors, odontogenic cysts and salivary gland tumors majority of which have been from the northern and southwestern regions. Arotiba et al. ${ }^{2}$ found that orofacial tumors constituted $20.2 \%$ out of a total of 342 patients seen over a period of 18 years in a study from Kano, Nigeria. The authors found squamous cell carcinoma and ameloblastoma as the most predominant orofacial tumors. This was similar to the report from Ile-Ife southwest Nigeria, which also found ameloblastoma as the most predominant benign jaw tumor. ${ }^{3}$ In southsouth Nigeria, there is paucity of epidemiological data on orofacial tumors. The only data that exist, to our knowledge, is that by Adebayo et al. ${ }^{10}$ from Port Harcourt. The authors' work was on spectrum of oral and maxillofacial conditions and was not specifically for maxillofacial tumors and allied conditions.

The aim of this study was to determine the types, prevalenceand demographic distribution of maxillofacial tumors, cysts and tumor-like lesions in a tertiary health institution located in the South-South region of Nigeria and to compare these data with previous reports. 


\section{Methods}

A retrospective analysis of the medical records and histological reports of patients with oral and maxillofacial tumors, cysts and tumor-like lesions who presented to the Maxillofacial Unit of University of Calabar Teaching Hospital from January 1997 to December 2007, a period of 11 years, was undertaken. Information on demographics, histological diagnosis and clinical presentation were obtained. The 2005 WHO criteria ${ }^{11}$ were adopted for the classification of odontogenic tumors and cyst of the jaws. The age limit for categorizations of tumor occurrence into pediatric or adult type was 19 years which is similar to that adopted by Aregbesola et al. ${ }^{3}$ The collected data were analyzed and a $\mathrm{p}$ value of less than 0.05 was considered significant.

\section{Results}

A total of 146 patients, aged 5-70 years (mean 30.5 \pm 12.9) were seen over the period of study. There were 96 males (65.8\%) and 50 females $(34.2 \%)$ giving a male to female ratio of almost $2: 1$. There was no gender difference in terms of age $(\mathrm{p}>0.05)$. Benign tumors accounted for $124,86.3 \%$ and malignant tumors (22, $13.7 \%$ ). Ameloblastoma was the most prevalent tumor observed $53(36.3 \%)$ representing $80.3 \%$ of the 66 odontogenic tumors (OT). The other OT included keratocystic odontogenic tumor $12(8.2 \%)$ and adenomatoid odontogenic tumor $1(0.7 \%)$. Other lesions include non-odontogenic tumors mainly represented by pyogenic granuloma $11(7.5 \%)$ and giant cell granuloma $4(2.7 \%)$; fibro-osseous lesions $19(13.0 \%)$, jaw cysts 20 ( $13.8 \%$ ) and pleomorphic adenoma presenting as parotid swelling $(1.4 \%)$. Malignant tumors comprised squamous cell carcinoma 8 (5.5\%), Burkitt's lymphoma 5(3.4\%), osteogenic sarcoma 5(3.4\%) and rhabdomyosarcoma 4 $(2.7 \%)$.

Table 1 shows the age distribution of 146 patients seen over 11 years in Calabar, Nigeria. The peak age of ameloblastoma was the fourth decade while that of fibrous dysplasia and ossifying fibroma were the second and third decade respectively. The age distribution of malignant tumors between pediatric and adult population was significant $\left(\mathrm{X}^{2}=457.33, \mathrm{df}=108, \mathrm{p}=0.001\right)$ (Table 1). This shows that certain malignant tumors are age specific. Thus, childhood malignant conditions were observed to peak during the first decade and squamous cell carcinomas were seen in the sixth and seventh decades of life (Table 1).

Table 1. Age Distribution of Oral and Maxillofacial Tumors and Tumor-like Lesions in 146 patients seen over 11 years Period

\begin{tabular}{|c|c|c|c|c|c|c|c|c|c|c|}
\hline Histological Types & $1-10$ & $\begin{array}{r}11-20 \\
\text { Years }\end{array}$ & $\begin{array}{r}\text { 21-30 } \\
\text { Years }\end{array}$ & $\begin{array}{l}31-40 \\
\text { Years }\end{array}$ & $\begin{array}{l}41-50 \\
\text { Years }\end{array}$ & $\begin{array}{l}51-60 \\
\text { Years }\end{array}$ & $\begin{array}{l}61-70 \\
\text { Years }\end{array}$ & $\begin{array}{l}\text { Total } \\
\text { Years }\end{array}$ & $\%$ & \\
\hline \multicolumn{11}{|l|}{ BENIGN TUMORS } \\
\hline \multicolumn{11}{|l|}{ Odontogenic Tumors } \\
\hline Adenomatoid Odontogenic Tumor & & 0 & 0 & 1 & 0 & 0 & 0 & 0 & 1 & 0.7 \\
\hline Ameloblastoma & & 0 & 0 & 8 & 35 & 9 & 0 & 1 & 53 & 36.3 \\
\hline Keratocystic Odontogenic Tumor 0 & & 4 & 5 & 3 & 0 & 0 & 0 & 12 & 8.2 & \\
\hline \multicolumn{11}{|l|}{ Non-odontogenic Tumors } \\
\hline Giant Cell Granuloma & 0 & 1 & 0 & 3 & 0 & 0 & 0 & 4 & 2.7 & \\
\hline Pyogenic Granuloma & 0 & 0 & 2 & 9 & 0 & 0 & 0 & 11 & 7.5 & \\
\hline Osteoma & 2 & 0 & 0 & 0 & 0 & 0 & 0 & 2 & 1.4 & \\
\hline \multicolumn{11}{|l|}{ Fibro-osseous Lesions } \\
\hline Fibrous Dysplasia & & 0 & 4 & 2 & 0 & 2 & 1 & 0 & 9 & 6.2 \\
\hline Osifying Fibroma & & 0 & 3 & 5 & 0 & 2 & 0 & 0 & 10 & 6.8 \\
\hline \multicolumn{11}{|l|}{ Cysts } \\
\hline Dentigerous Cyst & & 0 & 6 & 0 & 1 & 0 & 0 & 1 & 8 & 5.5 \\
\hline Radicular cyst & & 0 & 1 & 6 & 1 & 0 & 0 & 0 & 8 & 5.5 \\
\hline Nasoethmoidal Cyst & 0 & 1 & 2 & 0 & 0 & 0 & 0 & 3 & 2.1 & \\
\hline Globulomaxillary Cyst & 0 & 0 & 1 & 0 & 0 & 0 & 0 & 1 & 0.7 & \\
\hline \multicolumn{11}{|l|}{ Salivary gland tumors } \\
\hline Pleomorphic Adenoma & & 0 & 0 & 2 & 0 & 0 & 0 & 0 & 2 & 1.4 \\
\hline \multicolumn{11}{|l|}{ MALIGNANT TUMORS } \\
\hline Burkitt's Lymphoma & 5 & 0 & 0 & 0 & 0 & 0 & 0 & 5 & 3.4 & \\
\hline Rhabdomyosarcoma & 4 & 0 & 0 & 0 & 0 & 0 & 0 & 4 & 2.7 & \\
\hline Osteogenic Sarcoma & 0 & 0 & 4 & 1 & 0 & 0 & 0 & 5 & 3.4 & \\
\hline Squamous Cell Carcinoma & & 0 & 0 & 0 & 0 & 0 & 5 & 3 & 8 & 5.5 \\
\hline Total & & 11 & 20 & 38 & 53 & 13 & 6 & 5 & 146 & 100 \\
\hline
\end{tabular}

$\mathrm{X}^{2}=457.33, \mathrm{df}=108, \mathrm{p}=0.001$ 
The gender distribution of tumors and tumor-like lesions in 146 patients seen over the period of study is shown in Table 2. Majority of the maxillofacial tumors had predominant male distribution except for pyogenic granuloma, where female dominance was observed. The male to female ratios for benign and malignant tumors were 1:1.8 and 1:3.4 respectively (Table 2 ).

Table 2. Gender distribution of maxillofacial tumors and tumor-like lesions in 146 patients seen over 11 years Period

\begin{tabular}{|c|c|c|c|c|c|}
\hline \multirow{2}{*}{\multicolumn{2}{|c|}{ Histological Types }} & \multirow{2}{*}{$\begin{array}{l}\text { Female } \\
\text { n ( } \%)\end{array}$} & \multirow[t]{2}{*}{ Male } & \multicolumn{2}{|c|}{ Total } \\
\hline & & & & $\mathrm{n}(\%)$ & $\mathrm{n}(\%)$ \\
\hline \multicolumn{6}{|l|}{ Benign Tumors } \\
\hline \multicolumn{2}{|l|}{ Adenomatoid Odontogenic Tumor } & $0(0.0)$ & & $1(0.7)$ & $1(0.7)$ \\
\hline Ameloblastoma & $13(8.9)$ & & \multicolumn{2}{|c|}{$40(27.4) 53(36.3)$} & \\
\hline Dentigerous Cyst & & $1(0.7)$ & & $7(4.8)$ & $8(5.5)$ \\
\hline \multicolumn{2}{|l|}{ Keratocystic Odontogenic Tumor } & $0(0.0)$ & & $12(8.2)$ & $12(8.2)$ \\
\hline \multicolumn{2}{|l|}{ Radicular cyst } & $6(4.1)$ & & $2(1.4)$ & $8(5.5)$ \\
\hline \multicolumn{2}{|l|}{ Nasoethmoidal Cyst } & $1(0.7)$ & & $2(1.4)$ & $3(2.1)$ \\
\hline \multicolumn{2}{|l|}{ Globulomaxillary Cyst } & $1(0.7)$ & & $0(0.0)$ & $1(0.7)$ \\
\hline \multicolumn{2}{|l|}{ Fibrous Dysplasia } & $5(3.4)$ & & $4(2.7)$ & $9(6.1)$ \\
\hline \multicolumn{2}{|l|}{ Osifying Fibroma } & $3(2.1)$ & & $7(4.8)$ & $10(6.9)$ \\
\hline \multicolumn{2}{|l|}{ Giant Cell Granuloma } & $0(0.0)$ & & $4(2.7)$ & $4(2.7)$ \\
\hline \multicolumn{2}{|l|}{ Pyogenic Granuloma } & $11(7.5)$ & & $0(0.0)$ & $11(7.5)$ \\
\hline \multicolumn{2}{|l|}{ Osteoma } & $2(1.4)$ & & $0(0.0)$ & $2(1.4)$ \\
\hline Pleomorphic Adenoma & $2(1.4)$ & & $0(0.0)$ & & \\
\hline \multicolumn{6}{|l|}{ Malignant Tumors } \\
\hline \multicolumn{2}{|l|}{ Burkitt's Lymphoma } & $1(0.7)$ & & $4(2.7)$ & $5(3.4)$ \\
\hline \multicolumn{2}{|l|}{ Rhabdomyosarcoma } & $0(0.0)$ & & $4(2.7)$ & $4(2.7)$ \\
\hline \multicolumn{2}{|l|}{ Osteogenic Sarcoma } & $0(0.0)$ & & $5(3.4)$ & $5(3.4)$ \\
\hline \multicolumn{2}{|l|}{ Squamous Cell Carcinoma } & $4(2.7)$ & & $4(2.7)$ & $8(5.4)$ \\
\hline \multirow{2}{*}{\multicolumn{2}{|c|}{$\begin{array}{l}\text { Total } \\
\mathrm{X}^{2}=61.91, \mathrm{df}=18, \mathrm{p}=0.001\end{array}$}} & $50(34.3)$ & & $96(65.6)$ & $146(99.9)$ \\
\hline & & & & & \\
\hline
\end{tabular}

Table 3 shows the distribution of lesions according to site and main presenting complaints in 146 patients seen over 11 years period. Overall the tumors were distributed in an approximate ratio of 3:1 between the mandible and maxilla. Among the benign lesions predilection for the mandible was observed for ameloblastoma, keratocystic odontogenic tumor, dentigerous cyst and ossifying fibroma in this series. There was an equitable distribution of malignant tumors between mandible and maxilla with an approximate ratio of 1:1(Table 3). Across the series jaw swellings were the most common presentation $(98,67.1 \%)$, followed by pain $(23,15.9)$, toothache $(12,8.2 \%)$ and loose teeth $(11,7.5 \%)$ (Table 3). Half of the patients with malignant tumors presented with pain while only $9.7 \%$ of patients with benign tumors presented with pain. Ulceration which is commonly seen in malignant lesions especially squamous cell carcinoma was not observed. The duration of symptoms on presentation ranged from 1 month to 96 months (mean $23.32 \pm 15.72$ ) and this was not different for malignant or benign tumors ( $\mathrm{P}=0.886$ ). 
Table 3. Distribution of Maxillofacial Tumors and Tumor-like Lesions according to Site and Main Presenting complaints in 146 Patients seen over 11 years Period

Histological Types

Floor of Mouth Mandible

Maxilla

Parietal Bone

\title{
Parotid Total (\%)
}

Adenomatoid Odontogenic Tumor $0 \quad 0$

Ameloblastoma

$0 \quad 53$

$1 \quad 0$

$0 \quad 1(0.7)$

$0 \quad 53(36.3)$

Dentigerous Cysts

Odontogenic Keratocyst

\begin{tabular}{|c|c|c|c|c|c|c|c|c|}
\hline & 0 & 8 & & 0 & 0 & & 0 & $8(5.5)$ \\
\hline & 0 & 12 & & 0 & 0 & & 0 & $12(8.2)$ \\
\hline 0 & 3 & & 5 & 0 & & 0 & $8(5.5)$ & \\
\hline 0 & 0 & & 3 & 0 & & 0 & $3(2.1)$ & \\
\hline \multirow[t]{3}{*}{0} & 0 & & 1 & 0 & & 0 & $1(0.7)$ & \\
\hline & 0 & 0 & & 9 & 0 & & 0 & $9(6.2)$ \\
\hline & 0 & 10 & & 0 & 0 & & 0 & $10(6.8)$ \\
\hline 0 & 3 & & 1 & 0 & & 0 & $4(2.7)$ & \\
\hline \multirow[t]{2}{*}{0} & 5 & & 6 & 0 & & 0 & $11(7.5)$ & \\
\hline & 0 & 0 & & 0 & 2 & & 0 & $2(1.4)$ \\
\hline 0 & 0 & & 0 & 0 & & 2 & $2(1.4)$ & \\
\hline 0 & 2 & & 3 & 0 & & 0 & $5(3.4)$ & \\
\hline 0 & 2 & & 2 & 0 & & 0 & $4(2.7)$ & \\
\hline \multirow[t]{2}{*}{0} & 3 & & 2 & 0 & & 0 & $5(3.4)$ & \\
\hline & 1 & 4 & & 3 & 0 & & 0 & $8(5.5)$ \\
\hline 1 & 105 & & 36 & 2 & & 2 & $146(10$ & $0.0)$ \\
\hline
\end{tabular}

Presenting Complaints

\begin{tabular}{ll}
\multicolumn{2}{c}{ Benign Lesions } \\
$\mathbf{n}(\%)$ & $\mathbf{n}(\mathbf{\%})$ \\
$1(0.7)$ & $0(0.0)$ \\
$8(5.5)$ & $3(2.1)$ \\
$1(0.7)$ & $0(0.0)$ \\
$12(8.2)$ & $11(7.5)$ \\
$94(64.4)$ & $4(2.7)$ \\
$8(5.5)$ & $4(2.7)$
\end{tabular}

Malignant Lesions Total

n (\%)

$1(0.7)$

$11(7.5)$

$1(0.0)$

23(15.9)

Pain

$124(84.9)$

$22(15.1)$

$98(67.1)$

$12(8.2)$

Total

\begin{abstract}
(24)
\end{abstract}




\section{Discussion}

The observed late presentation of facial and intraoral swellings, often gross and disfiguring was similar to published reports. ${ }^{2,3}$ Benign lesions was the most common presentation (86.3\%) while malignant lesions accounted for $13.7 \%$. This sharply contrast previous reports from Nigeria and other parts of the world where benign lesions were only slightly more than malignant lesions in their distribution. The reason for this difference may be explained by the exclusion of cystic and reactive lesions from the previous studies. ${ }^{2}$ ${ }^{12-14}$ Generally, studies from the developed countries reports higher proportion of malignant jaw lesions than benign lesions when compared to reports from Africa. This observed difference may be explained in terms of relatively lower life expectancy among Africans compared to their Western counterparts. ${ }^{15}$

Overall, ameloblastoma was the most predominant lesion (36.3\%) and it accounted for $53(80.3 \%)$ out of the 66 odontogenic tumors (OT) observed in this series. The observed prevalence of $80.3 \%$, while comparable to the $83.3 \%$ obtained by Adebiyi et al. from Lagos, Nigeria ${ }^{16}$ is much higher than results of similar studies from Nigeria., 2, 17, 18 Our observed prevalence of ameloblastoma $(n=53 ; 80.3 \%)$ in our 11 year study period was comparable to that of Adebayo et al. $^{10}(\mathrm{n}=12 ; 80 \%)$ recorded in a period of 5 years from the same geopolitical zone in southern Nigeria. One reason adduced for the relatively high frequency of occurrence is the heterogeneous epithelial origin of ameloblastoma. ${ }^{19,20}$ The relatively high prevalence obtained for ameloblastoma could also be due to "harvesting phenomenon" as defined by Anand et al. ${ }^{21}$ Although the university of Calabar teaching hospital has been in existence for over 3 decades, active oral and maxillofacial services commenced only a decade and a half ago. Our study period appears to coincide with the time when patients with orofacial tumors, including cystic lesions, were referred to our centre because of availability of such services. Apart from the suggested high predilection of ameloblastoma for West Africans, ${ }^{22}$ it is most likely that the relatively high prevalence of ameloblastoma observed in the present study may also be due to the small size of odontogenic tumors recorded among our study population. This assertion is strenghtened when our observed prevalence $(80.3 \%$ out of 66 OT) is compared with those of Arotiba et al $^{17}\left(16 \%\right.$ out of 415 OT), Ladeinde et al ${ }^{18}$ (63\% out of 319 OT) and Odukoya ${ }^{25}$ (58.5\% out of 289 OT). The predilection for the mandible as well as the age and gender distribution is consistent with reports in the literature. ${ }^{16,23,24}$

In line with the recent WHO criteria ${ }^{11}$ odontogenic keratocysts categorized as odontogenic tumor (Keratocystic odontogenic tumor ( KCOT) was the next most common lesion (8.2\%) after ameloblastoma across the series. This is contrary to the findings in some studies where KCOT were reported as the most prevalent OT in studies that used the $2005 \mathrm{WHO}$ classification. ${ }^{25,}{ }^{26}$ Expectedly, inclusion of this cystic lesion as OT slightly $(8.2 \%)$ increased the overall proportion of OT in the series but it was much lower than the almost $50.0 \%$ increment observed by Servato et al. in a recent Brazilian study. ${ }^{26}$

The prevalence of odontogenic cysts has been shown to be in the range of $0.8-49.0 \%{ }^{22,}{ }^{28,}{ }^{29}$ We observed a prevalence of $11.0 \%$ in a period of 11 years. Our relatively lower prevalence value obtained for odontogenic cyst in this study may be due to exclusion of odontogenic keratocyst which was grouped under odontogenic tumor in the present analysis. Dentigerous and radicular cysts had peak age distribution of second and third decade respectively. All the dentigerous cysts observed in this series occurred in the mandible while the maxilla was the predominant site of occurrence for radicular cyst. The age and site distribution of these cystic lesions was consistent with earlier reports. ${ }^{28,30}$

Fibro-osseous lesions, distributed as fibrous dysplasia $(6.2 \%)$ and ossifying fibroma (6.8\%) collectively accounted for $13.0 \%$. Fibro-osseous lesions occurred over the second to the sixth decade with peak age of second and third decade for fibrous dysplasia and ossifying fibroma respectively. The often observed female predominance ${ }^{31,32}$ and predilection for the maxilla ${ }^{31,32}$ reported in the literature were not observed in the present study. The male to female ratio of 1:1.4 obtained in the present study agreed with the result of an earlier study from Nigeria. ${ }^{33}$ There was no significant difference in terms of occurrence in the mandible 10 $(6.8 \%)$ and maxilla $9(6.2 \%)$ in this series.

Pyogenic granuloma is a relatively common tumor-like lesion which includes $3.81 \%$ to $7 \%$ of all biopsy results of oral cavity lesions. ${ }^{34,35}$ The etiology of pyogenic granuloma is unknown, but it has been linked to trauma 
due to chronic irritation from calculus, faulty appliances or restorations..$^{35}$ The prevalence of $7.5 \%$ observed in the present study supports previous reports. ${ }^{34,35}$ Similarly, the age of occurrence, female predominance and preference for the maxilla observed in this study lend credence to published reports. ${ }^{33,34}$

Other less frequently observed benign lesions in the maxillofacial complex included giant cell granuloma, osteoma and pleomorphic adenoma presenting as parotid swelling. That only $2(1.4 \%)$ cases of salivary gland tumors were seen in the eleven year period of study was not surprising. In our institution various surgical subspecialties including general surgery, otorhinolaryngology and maxillofacial surgery are involved in the management of salivary gland tumors especially those that involve the major glands. This probably explains the low prevalence of salivary gland tumors observed in the present study.

The observed prevalence of $13.7 \%$ for malignant tumors while comparable to other reports ${ }^{13,36}$ is much lower than the $67.3 \%$ reported from East Africa by Kamulegeya and Kalmyanyama. ${ }^{14}$ The relatively lower figure for malignant tumors obtained in the present study and other similar studies may be due to inclusion of cysts and other tumor-like lesions in the data collection. Squamous cell carcinoma (5.5\%), the most common malignant histological diagnosis constituted about $36.4 \%$ of the malignant lesions in this series. This prevalence is lower than the $57.7 \%$ reported by Adekeye et al ${ }^{15}$ from a review of intraoral carcinomas in Northern Nigeria. This difference may be due to climatic differences. Our institution is within the rain forest belt of Nigeria with lower levels of sunshine compared to the dry savannah of the northern part of the country. This probably explains why lip cancer was not observed among our cases. Earlier studies from Nigeria observed frequent occurrences of oral cancers in lower age groups. ${ }^{15,}{ }^{37} \mathrm{The}$ observed peak age of occurrence of $6^{\text {th }}$ and $7^{\text {th }}$ decades agreed with reports from the Western world. ${ }^{7,8}$ All the squamous cell carcinoma were observed in patients over 50 years of age. The average life expectancy in Nigeria was previously estimated at 40 years. ${ }^{15}$ The result of our study tends to lend credence to a recent World Health Statistics Report ${ }^{38}$ that estimated the Nigerian life expectancy at birth for males as 47 years in 1990, 47 years in 2000 and 53 years in 2009 and that of females at 49 years in 1990, 48 years in 2000 and 54 years in
2009. The observed peak age of occurrence could also be explained by the small size of oral cancers (8) which were distributed within the $6^{\text {th }}$ and $7^{\text {th }}$ decades only.

Childhood malignant jaw tumors, represented by Burkitt's lymphoma (3.4\%) and rhabdomyosarcoma $(2.7 \%)$ and constituting $22.7 \%$ and $18.2 \%$ respectively of all malignant lesions, were observed to peak within the first decade of life, which agreed with previous reports. ${ }^{39,}{ }^{40}$ While the gender distribution of Burkitt's lymphoma is in support of published reports, ${ }^{3,9}$ the observed slight predilection for the maxilla contrasts with other reports that noted higher occurrence in the mandible., 3,14 The results of this study support the observed female predominance for rhabdomyosarcoma ${ }^{5}$ but differs from that of a study from Germany. ${ }^{41}$ Other malignant jaw tumors such as Hodgkin and nonHodgkin lymphomas, malignant salivary gland tumors, neural and vascular lesions were not observed in this series.

\section{Conclusion}

The epidemiology of oral and maxillofacial tumors observed in this study, with the exception of squamous cell carcinoma, is similar to previous reports from this part of the globe. Our observed age of occurrence of squamous cell carcinoma is higher than previous reports from Nigeria. Late presentation still remains the main challenging factor in the early detection and management of maxillofacial tumors. More awareness campaign is necessary, especially at the primary health care level, to educate the populace on the need for early presentation at treatment centers.

\section{References}

1. Theodorou DJ, Theodorou SJ, Sartorious DJ. Primary non-odontogenic tumors of the jawbones:an overview of essential radiographic findings. Clin Imaging 2003; 27: $59-70$

2. Arotiba JT, Adebola RA, Ajike SO, Adeola DS, Ladeinde A. Orofacial tumors and tumor-like lesions in Kano, Nigeria. Nig J Surg Research 2003; 5:134-139

3. Aregbesola SB, Ugboko VI, Akinwande JA, Arole GF, Fagade OO. Orofacial tumors in suburban Nigerian children and adolescents. Br J Oral Maxillofac Surg 2005; 43: 226-231

4. Mohamed A, Singh AS, Raubenheimer EJ, Bouckaert MMR . Adenomatoid odontogenic tumor: review of the literature and an analysis of 33 cases from South 
Africa. Int J Oral Maxillofac Surg 2010; 39: 843-846

5. Abdulai AE, Nwamah IK, Gyasi R. Head and Neck tumors in Ghanaian children. A 20 year review. Int J Oral Maxillofac Surg 2012; 41:1378-1382

6. Sankaranarayan R. Oral cancer in India:an epidemiological and clinical review. Oral Surg Oral Med Oral Pathol 1990; 69:325-330

7. Binnie WH. A perspective of oral cancer. Proc R Soc Med 1976; 69:737-740

8. Krutchkoff DJ, Chen J, Eissenberg E, Katz RV. Oral cancer: a survey of 566 cases from the University of Connecticut oral pathology biopsy service 1975-1986. Oral Surg Oral Med Oral Pathol 1990; 70:192-198

9. Wakiaga JM, Oyango JF, Awange DO. Clinico-pathological analysis of jaw tumors and tumor-like conditions at the Kenyanta National Hospital. East Afr Med J 1997; 74(2): 65-68

10. Adebayo ET, Ajike SO, Abite MG. Audit of oral and maxillofacial surgical conditions seen at Port Harcourt, Nigeria. Ann Afr Med 2008; 7: 29-34

11. Barnes L, Everson JW, Reichart P, Sidransky D. Pathology and genetics of head and neck tumors. Lyon IARC Press 2005; p.284-327

12. Rafindadi AH, Ayuba SI. Tumours and tumour-like conditions of the jaw seen in Zaria, Nigeria. Ann Afr Med 2002; 1:72-79

13. Tay ABG. A 5 year survey of oral biopsies in an oral surgical unit in Singapore:1993-1997. Ann Acad Med Singapore 1999; 28:665-671

14. Kamulegeya A, Kalyanyama BM. Oral maxillofacial neoplasms in an East African population:a 10 year retrospective study of 1863 cases using histopathological reports.BMC Oral Health 2008; 8:19 doc;10.1186/1472 6831-8-19

15. Adekeye EO, Asamoa E, Cohen B. Intraoral carcinoma in Nigeria: a review of 137 cases. Ann R Coll Surg Engl 1985; 6:181-182

16. Adebiyi KE, Odukoya O, Taiwo EO. Ectodermal odontogenic tumors: analysis of 197 Nigerian cases. Int J Oral Maxillofac Surg 2004; 13:766-770

17. Arotiba JT, Ogunbiyi JO, Obiechina AE. Odontogenic tumors: a 15-year review from Ibadan, Nigeria. Br J Oral Maxillofac Surg 1997; 35:363-367

18. Ladeinde AL, Ajayi OF, Ogunlewe MO, Adeyemo WL, Arotiba GT et al. Odontogenic tumors: A review of 319 cases in a Nigerian teaching hospital. Oral Surg Oral Med Oral Pathol Oral Radiol Endod 2005; 99: 191 195

19. Mendenhall WM, Werning JW, Fernandes R, Malyapa RS, Mendenhall NP. Ameloblastoma. Am J Clin On- col 2007;30:645-648.

20. Tajima Y, Yokose S, Sakamoto E, Yamatoto Y, Utsu$\mathrm{mi} \mathrm{N}$. Ameloblastoma arising in calcifying odontogenic cyst. Report of a case. Oral Surg Oral Med Oral Pathol 1992; 74: 776-779

21. Anand SV, Davy W, Cohen B. Tumors of the jaws in West Africa: a review of 256 patients. Br Surg 1967; 54:910-917

22. Mosadomi A. Tumors, cysts and allied lesions of the jaws and oral mucosa in Lagos, Nigeria, 1969-1974. Int J Oral Surg 1975; 4:219-224

23. Adekeye EO. Ameloblastoma of the jaws. A Survey of 109 Nigerian patients. J Oral Surg 1980; 38: 36-41

24. Odukoya O. Odontogenic tumors: analysis of 289 Nigerian cases. J Oral pathol Med 1995; 24: 454-457

25. Tawfik MA, Zyadia MM. Odontogenic tumors in Dakahlia, Egypt: analysis of 82 cases. Oral Surg Oral Med Oral Pathol Oral radiol Endod 2010; 109: 67-73

26. Avelar RI, Antunes AA, Santos T, de S, Andrade ES et al. Odontogenic tumors: clinical and pathology study of 238 cases. Braz J Otorbinolaryngol 2008; 74:668-673 27. Servato JPS, Prieto-Oliveira P, de Faria PR, Loyola AM, Cardoso SV. Odontogenic tumors: 240 cases diagnosed over 31 years at a Brazillian university and a review of international literature. Int J Oral Maxillofac Surg bttp://dx.doi.org/10.1016/j.ijom.2012.05.008

28. El Gehani R, Krishnan B, Orafi H. The prevalence of inflammatory and developmental odontogenic cysts in a Libyan population. Libyan J Med 2008; 3(2): $75-77$ 29. Arotiba JT, Lawayin JO, Obiechina AE. Pattern of occurrence of odontogenic cysts in Nigerians. East Afr Med J 1998; 75: 664-666

30. Lawal AO, Adisa AO, Sigbeku OF. Cysts of the orofacial region: a Nigerian experience. J Oral Maxillofac Pathol 2012; 16(2): 167-171

31. Williams AO, Browne PM, Akinosi JO. Fibro-osseus lesions of the jaws in Nigeria. J Natl Med Assoc 1974; 66:185-191

32. Waldron CA, Giansanti JS. Benign fibro-osseus lesions of the jaws: a clinic-radiologic histologic review of 66 cases. Oral Surg 1973; 35:190-201

33. Ajagbe HA, Daramola JO. Fibro-Osseous Lesions of the Jaw: A Review of 133 Cases from Nigeria. J Natl Med Assoc 1983; 75 (6):593-598

34. Lawoyin JO, Arotiba JT, Dosumu OO. Oral pyogenic granuloma: A review of 38 cases from Ibadan, Nigeria. Br J Oral Maxillofac Surg. 1997; 35(3):185189.

35. Saghafi S, Zare-Mahmoodabadi R, Danesh-Sani SA, Mahmoodi P, Esmaili M. Oral Pyogenic Granu- 
loma: A Retrospective Analysis of 151 Cases in an Iranian Population. International Journal of Oral and Maxillofacial Pathology 2011; 2(3):3-6

36. Jones AV, Franklin CD. An analysis of oral and maxillofacial pathology found in adults over a 30-year period. J Oral Pathol Med 2006; 35:392-401

37. Daramola JO, Ajagbe HA, Oluwasanmi JO. Pattern of oral cancer in a Nigerian population. Br J Oral Surg 1979; 17: 123-128

38. World Health Organization: global status report,
April 2011

39. Bhaskar SN. Oral tumors of infancy and childhood. J Pediatr 1963; 63: 195-210

40. Sato M, Tanaka N, Sato T, Amagasa T. Oral and maxillofacial tumors in children: a review. Br J Oral Maxillofac Surg 1997; 35:92-95

41. Gosepath J, Spix C, Talebloo B, Blettner M, Mann WJ. Incidence of childhood cancer of the head and neck in Germany. Ann Oncol Off J Eur Soc Med Oncol 2007; 18 (10): 1716-1721 